\title{
EKSPLORASI POLA PADA SISWA SEKOLAH DASAR
}

\author{
Rusdiana \\ Program Studi Pendidikan Matematika, Universitas Mulawarman \\ Email: rusdiana@fkip.unmul.ac.id
}

\begin{abstract}
ABSTRAK
Tujuan penelitian ini adalah untuk mengklasifikasikan hasil pekerjaan siswa dalam menyelesaikan permasalahan pola. Penelitian ini dilakukan terhadap siswa sekolah dasar kelas 1 dan 2 . Instrumen penelitian berupa lembar tugas (soal). Tanpa adanya pengajaran formal mengenai pola, ternyata siswa mampu menyelesaikan permasalahan pola sederhana. Siswa mampu melanjutkan dan mengidentifikasi aturan pola sederhana. Meskipun bekerja dengan pola nampaknya merupakan hal yang baru bagi siswa kelas 1 dan kelas 2, namun peneliti menyarankan bahwa siswa di tahun-tahun awal sekolah dasar sebaiknya diberikan kesempatan untuk menyelesaikan permasalahan pola sederhana karena hal tersebut merupakan awal dari berpikir fungsional dan dapat membantu dalam mengembangkan pemahaman mengenai hubungan antar operasi, terutama hubungan invers.
\end{abstract}

Kata kunci: Pola, Siswa Sekolah Dasar, Berpikir Fungsional.

\begin{abstract}
The purpose of this study is to classify the results of students' work on problem patterns. This research was conducted on elementary school students in grades 1 and 2 . The research instrument is task (question). Without formal teaching about patterns, it turns out students can solve simple pattern problems. Students can continue and identify simple pattern rules. Although working with patterns seems to be new to students in grade 1 and grade 2, the researcher suggests that students in the early years of elementary school should be allowed to solve simple pattern problems because they are the beginning of functional thinking and can help in developing an understanding of the relationship between operations, especially inverse.
\end{abstract}

Keywords: Pattern, Elementary School Students, Functional Thinking.

\section{PENDAHULUAN}

Aljabar dapat dipandang sebagai bahasa simbolik yang memungkinkan seseorang mengekspresikan hubungan dan generalisasi, biasanya melibatkan bilangan untuk memecahkan masalah tanpa perhitungan numerik secara luas yang mungkin diperlukan (misalnya, ketika menggunakan trial and error) (Papic dkk, 2011). Kieran dalam Kieran (2004) mendefinisikan berpikir aljabar 
sebagai sebuah pendekatan bagi situasisituasi kuantitatif yang menekankan pada aspek hubungan umum dengan menggunakan alat-alat yang tidak selalu berupa huruf simbolik, tetapi pada akhirnya penggunaan huruf tersebut dapat digunakan sebagai dukungan kognitif untuk memperkenalkan dan mempertahankan wacana yang lebih tradisional dari aljabar yang ada di sekolah. Representasi dan analisis situasi serta struktur secara matematis adalah komponen utama dari berpikir aljabar. NCTM (2000) menegaskan bahwa guru dapat mempersiapkan siswa untuk sukses dalam aljabar jika mulai mengajar siswa untuk berpikir secara aljabar sejak dini. Bekerja dengan pola termasuk berpikir aljabar (Papic dkk, 2011). Penelitian terhadap perkembangan pola dan struktur matematis pada anak-anak pra sekolah beberapa tahun terakhir mengalami peningkatan (Mulligan dkk, 2008; Papic dkk, 2009; Papic, Mulligan \& Micthelmore, 2011). Hasil penelitian tersebut memberikan bukti empiris bahwa anak-anak pra sekolah dapat mengembangkan konsep pola yang kompleks dan berpikir pra aljabar berkembang melalui kesadaran struktural tentang pola.

Umumnya anak pra sekolah dan Sekolah Dasar (SD) mengalami tiga jenis pemolaan matematis, yaitu: pola struktur spasial, pola pengulangan dan pola pertumbuhan (growing patterns). Hasil penelitian Papic dkk (2011) menunjukkan bahwa anak-anak dapat mengembangkan konsep dan strategi pola secara piawai sebelum masuk ke Taman Kanak-kanak dan bahwa anakanak usia 4 tahun dapat terlibat dalam berpikir pra aljabar. Aktivitas pola terutama dengan pola pengulangan dapat mengembangkan konsep matematis umum bagi anak-anak seperti mengurutkan, membandingkan, barisan, klasifikasi, abstraksi dan aturan generalisasi serta membuat prediksi. Konsep-konsep tersebut akan membantu perkembangan penalaran matematis bagi anak-anak (Mulligan \& Mitchelmore, 2009). Kontribusi utama dari pekerjaan pola adalah mengembangkan prinsip aljabar tentang generalisasi, yaitu proses ketika penggunaan komponen yang sama dalam kasus tertentu dari pola dapat diidentifikasi.

Artikel ini mendeskripsikan bagaimana siswa sekolah dasar kelas 1 dan kelas 2 dalam mengeksplorasi pola sederhana yaitu berbentuk pola pertumbuhan. Pola pertumbuhan terdiri dari barisan elemen-elemen yang naik (atau turun) secara sistematis Contoh sederhana dari pola pertumbuhan adalah barisan bilangan bulat $2,4,6,8, \ldots$. Jenis tertentu dari berpikir aljabar adalah berpikir fungsional (Papic dkk (2011), yang terjadi ketika individu memandang generalisasi yang menghubungkan dua himpunan objek (misalnya fungsi, korelasi, dan transformasi). Hasil penelitian Warren \& Cooper (2008) terhadap siswa sekolah dasar usia 8 tahun mengungkap bahwa, siswa tidak hanya mampu berpikir mengenai hubungan antara dua kelompok data, tetapi dapat mengekspresikan hubungan tersebut dalam bentuk yang sangat abstrak. Ketika diberikan pola pertumbuhan visual yang sederhana, siswa mampu menggambar pola dengan benar walaupun posisi pola yang 
diberikan berbeda. Memperlakukan pola sederhana dalam barisan elemen sebagai hubungan antar tiap elemen dan letaknya dalam barisan adalah contoh mendasar dari berpikir fungsional.

Telah banyak penelitian yang dilakukan mengenai pola pertumbuhan (Warren, 2005; Papic \& Mulligan, 2007; Mulligan dkk, 2008; Miller \& Warren, 2012). Penelitian Papic \& Mulligan (2007) mengungkap bahwa siswa pra sekolah di Australia mampu mengidentifikasi, memperluas, merepresentasikan dan menjustifikasi pola bilangan segitiga dan persegi. Siswa Taman Kanak-kanak ternyata memiliki kesadaran tentang pola dan struktur matematis, siswa mampu melakukan simbolisasi dan justifikasi dalam pengulangan dan pola pertumbuhan (Mulligan dkk, 2008). Untuk penelitian pada siswa sekolah dasar, menurut Miller \& Warren (2012) ternyata siswa pribumi di Australia tahun ke-2 dan ke-3 mampu bekerja dengan pola pertumbuhan bahkan sebelum pengajaran formal. Warren (2005) juga menambahkan bahwa setelah pengajaran formal mengenai pola pertumbuhan, ada perkembangan pemahaman siswa mengenai pola pertumbuhan dan siswa mampu menggambarkan dalam istilah yang lebih umum hubungan diantara pola dan posisi pola.

Pemahaman yang baik tentang konsep pola sederhana sangat penting, karena memberikan cara yang konkrit bagi siswa untuk mengeksplor gagasan generalisasi dalam bentuk aturan pola. Untuk siswa sekolah menengah, bekerja dengan pola linear dapat berfungsi sebagai pengenalan grafik fungsi.
Bekerja dengan pola terutama pola sederhana membuat siswa mampu mengembangkan pemahaman yang baik mengenai fungsi karena masing-masing elemen berhubungan dengan elemen lainnya, dan aturan fungsi menggambarkan bagaimana elemen dari satu kelompok data berhubungan dengan elemen di kelompok data lainnya. Demikian pula dengan pola yang kaya dan beraneka ragam yang dibuat oleh anak-anak pra sekolah secara alamiah akan berlanjut pada tahun-tahun di sekolah dasar yang akan membantu mereka dalam mengeksplorasi sifat matematis dalam beragam masalah (Luken dkk, 2014; Brizuela dkk, 2013).

\section{METODE PENELITIAN}

Subjek penelitian ini adalah siswa kelas 1 sebanyak 3 orang (ketiganya laki-laki) dan kelas 2 sebanyak 3 orang (2 perempuan dan 1 laki-laki). Subjek dipilih karena kemampuan berkomunikasi yang baik. Siswa diberikan lembar tugas mengenai pola partumbuhan dan diminta untuk menjelaskan jawaban yang mereka berikan. Pola pertumbuhan yang dipilih di dalam lembar kerja adalah yang secara visual eksplisit, di mana hubungan antara pola secara mudah dapat dipahami oleh siswa.

\section{HASIL PENELITIAN DAN PEM- BAHASAN}

Siswa diminta menjelaskan jawaban mereka mengenai pola pertumbuhan yang mereka buat. Dari penjelasan tersebut, kategori jawaban siswa dapat dikelompokkan ke dalam: (a) respon 
spasial; biar banyak, (b) respon secara numeris (Miller \& Warren, 2012); bertambah sebanyak dua; (c) respon aditif, dijumlah.

Contoh pekerjaan siswa yang termasuk kategori respon spasial dapat dilihat pada Gambar 1.
Subjek 2 : Satu

Peneliti : Ekornya ada berapa?

Subjek 2: 3 (sambil menunjuk gambar ulat dengan ekor 3)

Peneliti : Yang sebelahnya ada berapa?

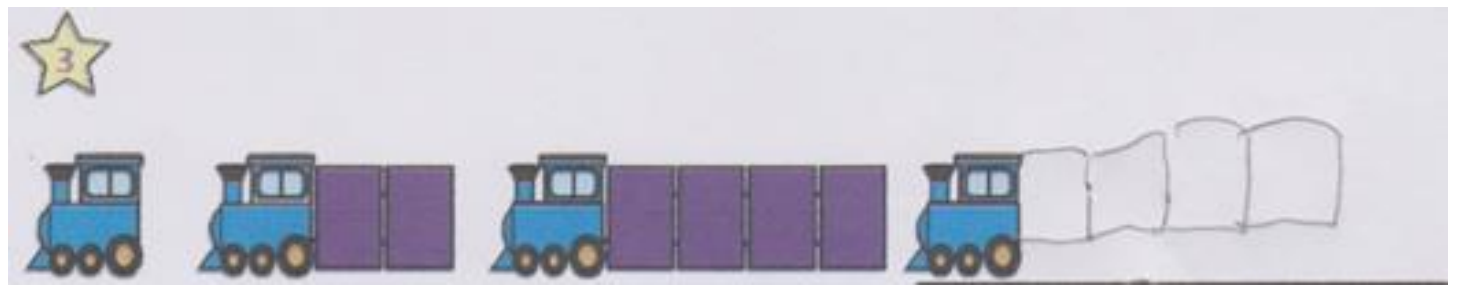

Gambar 1. Hasil pekerjaan siswa kelas 1

Berikut petikan wawancara dengan Subjek 1 siswa kelas 1 .

Peneliti : itu gambar apa ya?

Subjek 1 : ada 4 gerbong kereta api?

Peneliti : kenapa ada 4 ?

Subjek 1 : biar banyak

Contoh pekerjaan siswa yang termasuk kategori respon secara numeris dapat dilihat pada Gambar 2.
Subjek 2 : Ada 5

Peneliti : Kira-kira sebelahnya lagi ada berapa ya?

Subjek 2 : Ada 7

Peneliti : Oh pintar, kenapa ada 7 nak?

Subjek 2 : Soalnya ditambah 2

Contoh pekerjaan siswa yang termasuk kategori respon aditif dapat dilihat pada Gambar 3.

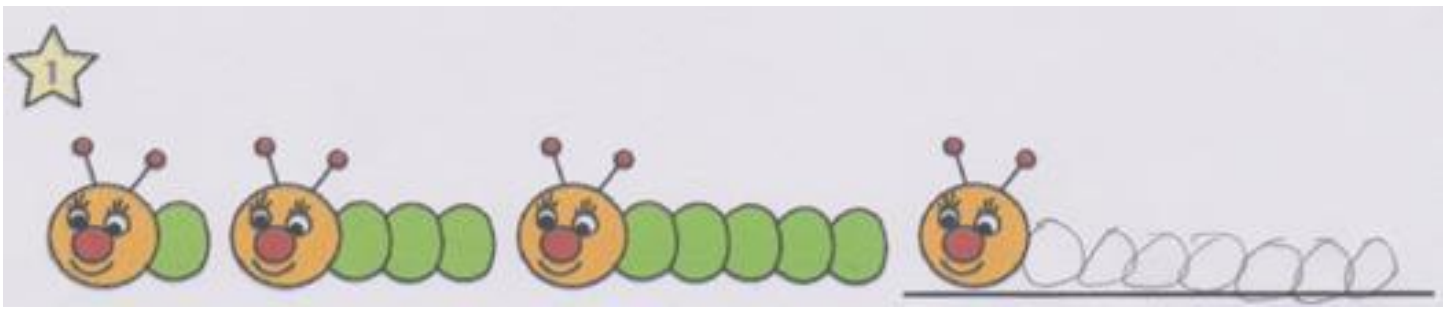

Gambar 2. Hasil pekerjaan siswa kelas 2

Berikut petikan wawancara dengan Subjek 2.

Peneliti : itu gambar apa ya?

Subjek 2 : Ini gambar apa ini? (masih bingung)

Peneliti : Oh yang pertama ada apa ya dibelakangnya?
Berikut petikan wawancara dengan Subjek 3.

Peneliti : Lagi buat apa?

Subjek 3 : Rumah

Peneliti : Rumahnya ada yang kecil, ada yang besar ya. Ada berapa jumlahnya? 
Subjek 3 : ada 6

Peneliti : Dapat darimana 6 nya?

Subjek 3 : dijumlah (sambil menunjuk

rumah 1,2 dan 3 ) dinamis (misalnya, jika $x$ bertambah 1 , maka $y$ bertambah 3) dan (3) hubungan
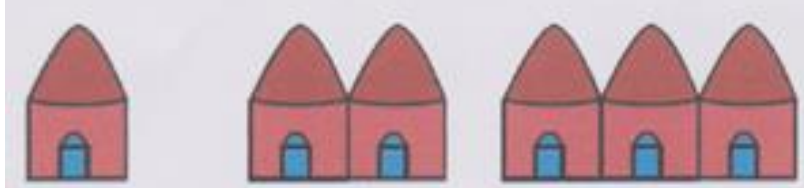

B) $\theta$ हि

Gambar 3. Hasil pekerjaan siswa kelas 2

Berpikir fungsional berhubungan dengan perkembangan pemikiran aljabar (McEldon \& Johnson, 2010). Berpikir fungsional terjadi ketika individu memandang generalisasi yang menghubungkan dua himpunan objek (misalnya fungsi, korelasi, dan transformasi). Blanton \& Kaput (2011) secara luas mengkonseptualisasikan berpikir fungsional yaitu untuk menggeneralisasi pola dan hubungannya dengan menggunakan bahasa yang beragam dan alat-alat representasi serta memperlakukan hubungan yang digeneralisasi atau fungsi yang hasilnya adalah sebagai objek matematis yang berguna bagi siswa sendiri. Terdapat tiga cara dalam menganalisis pola dan hubungannya sebagai kerangka untuk membahas jenis pemikiran fungsional yang ditemukan di dalam kelas (Smith dalam Blanton \& Kaput, 2011), yaitu: (1) recursive patterning yaitu menemukan variasi dalam urutan nilai-nilai; (2) pemikiran covariational yang didasarkan pada kemampuan menganalisis dua kuantitas yang bervariasi secara bersamaan dan menjaga perubahan itu sebagai bagian dari deskripsi fungsi yang eksplisit dan korespondensi yang didasarkan pada kemampuan mengidentifikasi korelasi diantara variabel (misalnya $y$ adalah 3 kali $x$ ditambah 2). Pola yang digunakan untuk mengenalkan aljabar pada siswa adalah pola pertumbuhan (Warren \& Cooper, 2008). Siswa diminta untuk membentuk hubungan antara pola dan posisi pola serta menggunakan generalisasi tersebut untuk menghasilkan langkah-langkah pola untuk posisi yang lain, mereka diminta untuk mempertimbangkan kembali pola sebagai fungsi (yaitu sebagai hubungan antara pola dan posisinya). Umumnya ini melibatkan representasi visual, mendaftar data dalam tabel (posisi dan jumlah elemen pada saat itu), dan dari tabel tersebut mengidentifikasi hubungan antara dua kelompok data.

Memperlakukan pola pertumbuhan dalam barisan elemen sebagai hubungan antara tiap elemen dan letaknya dalam barisan adalah contoh mendasar dari berpikir fungsional. (Papic dkk, 2011). Contohnya adalah penjumlahan yang dapat direpresentasikan sebagai perubahan; jika ada 3 permen kemudian ditambah dengan 2 permen, berapa permen yang ada? 
Contoh seperti ini menurut Warren \& Cooper (2005) adalah awal dari berpikir fungsional. Berpikir fungsional dapat membantu dalam mengembangkan pemahaman mengenai hubungan antar operasi, terutama hubungan invers, misalnya: jika bilangan saya bertambah 2 dan sekarang saya memiliki 8 , berapa bilangan saya sebelumnya? Menurut Warren \& Cooper, ide-ide tersebut membantu siswa dalam memahami fungsi di jenjang yang lebih tinggi, membantu siswa mengeksplor aritmetika sebagai sebuah perubahan, membuat koneksi antara beragam operasi (yaitu, bahwa penjumlahan adalah invers dari pengurangan) dan memberikan kesempatan untuk melakukan konjektur dan justifikasi sejak dini.

\section{KESIMPULAN}

Hasil penelitian ini menunjukkan bahwa siswa sekolah dasar kelas 1 dan 2 mampu menyelesaikan permasalahan pola pertumbuhan bahkan sebelum pengajaran formal mengenai pola pertumbuhan. Hasil penelitian ini sejalan dengan temuan Blanton \& Kaput (2004) dan Warren \& Cooper (2005, 2008) bahwa siswa (young students) mampu berpikir fungsional lebih awal daripada yang diperkirakan serta anak usia 8 tahun dapat mempelajari berpikir fungsional dengan baik melalui analisis terhadap pola pertumbuhan.

\section{DAFTAR PUSTAKA}

Blanton, M. L., \& Kaput, J. J. (2004). Elementary Grades Students' Capacity for Functional Thinking. International Group For The Psy- chology Of Mathematics Education.

Blanton, M. L., \& Kaput, J. J. (2011). Functional thinking as a route into algebra in the elementary grades. In Early algebraization (pp. 523). Springer.

Brizuela, B. M., Martinez, M. V., \& Cayton-Hodges, G. A. (2013). The impact of early algebra: Results from a longitudinal intervention. REDIMAT-Journal of Research in Mathematics Education, 2(2), 209-241.

Kieran, C. (2004). Algebraic thinking in the early grades: What is it. The Mathematics Educator, 8(1), 139151.

Lüken, M. M., Peter-Koop, A., \& Kollhoff, S. (2014). Influence of Early Repeating Patterning Ability on School Mathematics Learning. North American Chapter of the International Group for the Psychology of Mathematics Education.

McEldoon, K. L., \& Rittle-Johnson, B. (2010). Assessing elementary students' functional thinking skills: The case of function tables. Proceedings of the 32nd Annual Meeting of the North American Chapter of the International Group for the Psychology of Mathematics Education, 202.

Miller, J., \& Warren, E. (2012). An exploration into growing patterns with young Australian Indigenous students.

Mulligan, J., \& Mitchelmore, M. (2009). Awareness of pattern and structure in early mathematical development. Mathematics Education Research Journal, 21(2), 33-49. 
Mulligan, J., Mitchelmore, M., Marston, J., Highfield, K., \& Kemp, C. (2008). Promoting mathematical pattern and structure in the first year of schooling: An intervention study. Proceedings of the Joint Meeting of PME, 32, 1-8.

Papic, M. M., Mulligan, J. T., \& Mitchelmore, M. C. (2011a). Assessing the development of preschoolers' mathematical patterning. Journal for Research in Mathematics Education, 42(3), 237-269.

Papic, M. M., Mulligan, J. T., \& Mitchelmore, M. C. (2011b). Assessing the development of preschoolers' mathematical patterning. Journal for Research in Mathematics Education, 42(3), 237-269.

Papic, M. M., Mulligan, J. T., \& Mitchelmore, M. C. (2009). The growth of mathematical patterning strategies in preschool children. Conference of the International Group for the Psychology of Mathematics Education (33rd: 2009), 4-329.

Papic, M., \& Mulligan, J. (2007). The growth of early mathematical patterning: An intervention study.

NCTM. (2000). Standards for school mathematics. Reston, VA: National Council of Teachers of Mathematics.

Warren, E. (2005). Young Children's Ability to Generalise the Pattern Rule for Growing Patterns. International Group for the Psychology of Mathematics Education, 4, 305-312.

Warren, E., \& Cooper, T. (2005). Introducing Functional Thinking in Year 2: A case study of early algebra teaching. Contemporary Issues in Early Childhood, 6(2), 150-162.

Warren, E., \& Cooper, T. (2008). Generalising the pattern rule for visual growth patterns: Actions that support 8 year olds' thinking. Educational Studies in Mathematics, 67(2), 171-185. 
| Jurnal PRIMATIKA, Volume 9, Nomor 1, Juni 2020 